\title{
Replacing corn silage with different forage millet silage cultivars: Effects on milk yield, nutrient digestion, and ruminal fermentation of lactating dairy cows
}

\author{
T. Brunette ${ }^{*}$ B. Baurhoo, $t^{1}$ and A. F. Mustafa ${ }^{* 1}$ \\ *Department of Animal Science, MacDonald Campus, McGill University, Sainte-Anne-de-Bellevue, Quebec, H9X 3V9, Canada \\ †Bélisle Solution Nutrition Inc., St-Mathias-sur-Richelieu, Quebec, J3L 6A7, Canada
}

\begin{abstract}
This study investigated the effects of dietary replacement of corn silage (CS) with 2 cultivars of forage millet silages [i.e., regular millet $(\mathrm{RM})$ and sweet millet $(\mathrm{SM})]$ on milk production, apparent total-tract digestibility, and ruminal fermentation characteristics of dairy cows. Fifteen lactating Holstein cows were used in a replicated $3 \times 3$ Latin square experiment and fed (ad libitum) a high-forage total mixed ration (68:32 forage:concentrate ratio). Dietary treatments included CS (control), RM, and SM diets. Experimental silages constituted $37 \%$ of each diet DM. Three ruminally fistulated cows were used to determine the effect of dietary treatments on ruminal fermentation and totaltract nutrient utilization. Relative to CS, RM and SM silages contained $36 \%$ more crude protein, $66 \%$ more neutral detergent fiber (NDF), and $88 \%$ more acid detergent fiber. Cows fed CS consumed more dry matter (DM; 24.4 vs. $22.7 \mathrm{~kg} / \mathrm{d}$ ) and starch (5.7 vs. 3.7 $\mathrm{kg} / \mathrm{d}$ ), but less NDF (7.9 vs. $8.7 \mathrm{~kg} / \mathrm{d}$ ) than cows fed RM or SM. However, DM, starch and NDF intakes were not different between forage millet silage types. Feeding RM relative to CS reduced milk yield (32.7 vs. $35.2 \mathrm{~kg} / \mathrm{d}$ ), energy-corrected milk (35.8 vs. 38.0 $\mathrm{kg} / \mathrm{d}$ ) and SCM (32.7 vs. $35.3 \mathrm{~kg} / \mathrm{d}$ ). However, cows fed SM had similar milk, energy-corrected milk, and solids-corrected milk yields than cows fed CS or RM. Milk efficiency was not affected by dietary treatments. Milk protein concentration was greatest for cows fed CS, intermediate for cows fed SM, and lowest for cows fed RM. Milk concentration of solids-not-fat was lesser, whereas milk urea nitrogen was greater for cows fed RM than for those fed CS. However, millet silage type had no effect on milk solids-not-fat and milk urea nitrogen levels. Concentrations of milk fat, lactose and total solids were not affected by silage type. Ruminal $\mathrm{pH}$
\end{abstract}

\footnotetext{
Received January 30, 2014.

Accepted May 27, 2014.

${ }^{1}$ Corresponding authors: bbaurhoo@belisle.net and arif.mustafa@ mcgill.ca
}

and ruminal $\mathrm{NH}_{3}-\mathrm{N}$ were greater for cows fed $\mathrm{RM}$ and SM than for cows fed CS. Total-tract digestibility of $\mathrm{DM}$ (average $=67.9 \%), \mathrm{NDF}$ (average $=53.9 \%$ ), crude protein (average $=63.3 \%$ ), and gross energy (average $=67.9 \%$ ) were not influenced by dietary treatments. It was concluded that cows fed CS performed better than those fed RM or SM likely due to the higher starch and lower NDF intakes. However, no major differences were noted between the 2 forage millet silage cultivars.

Key words: corn silage, forage millet silage, dairy cow, milk yield

\section{INTRODUCTION}

Corn silage (CS) is a preferential and abundantly used forage in dairy cow nutrition, principally due to its high DM yield, single-cut harvest at optimum DM contents, high $\mathrm{NE}_{\mathrm{L}}$ concentration, capacity to sustain high milk yields, and good ensiling characteristics. However, in many temperate regions of Canada, the production of CS is risky and low-yielding, despite the use of shortseason cultivars. Indeed, the growing season with warm temperatures (above $15^{\circ} \mathrm{C}$ ) is only between 70 and $90 \mathrm{~d}$. Moreover, the high $\mathrm{N}$ fertilizer application rate that CS necessitates makes it uneconomical for cold regions. Alfalfa and perennial grasses are the most commonly used forages on such dairy farms. But, dairy producers are often challenged with on-farm forage shortages, especially during conditions of alfalfa winter kill. Therefore, we hypothesize that forage pearl millet may be used as an emergency forage or routinely as a new forage option by dairy producers located in temperate regions.

Pearl millet [Pennisetum glaucum (L.) R.] is an annual semi-arid tropical grass with high biomass yield and low $\mathrm{N}$ fertilizer requirement, and is drought resistant and adaptable to low soil $\mathrm{pH}$ (Maiti and Wesche-Ebeling, 1997). Because of its adaptability to harsh conditions, millet can be grown in areas unfavorable to other cereals, such as corn (Hanna, 1995). Data regarding the feeding value of pearl millet silage to lactating cows are limited. Moreover, from the few published studies that have investigated the nutritive values of pearl millet, 
findings are highly inconsistent. For example, pearl millet (harvested after $66 \mathrm{~d}$ of growth; $23 \% \mathrm{DM}$ ) silage fed to lactating cows in place of alfalfa silage plus CS had no effect on milk yield or milk fat concentration, but reduced DMI and milk protein levels (Messman et al., 1992). Kochapakdee et al. (2002) have shown reduced milk production and milk protein levels when cows were fed diets containing pearl millet silage (30\% DM) compared with temperate CS. In contrast, feeding pearl millet (harvested at $80 \mathrm{~d}$ of growth; $27 \% \mathrm{DM}$ ) silage relative to CS had similar effects on feed intake, milk yield, and milk efficiency (Amer and Mustafa, 2010).

Pearl millet is mostly grown to grain in many African and Asian countries. However, unlike grain millet cultivars, forage pearl millet offer flexible harvest dates. Indeed, forage pearl millet may be harvested from vegetative (i.e., $24 \% \mathrm{DM})$ to more mature $(32 \% \mathrm{DM})$ stages, thus making it extremely suitable for the cold regions. In this study, we were also interested in testing forage pearl millet cultivars containing high levels of watersoluble carbohydrates (WSC). High WSC is reported to improve ensilability of forages by accelerating lactic acid production (Adesogan et al., 2004). Therefore, the objectives of this study were to determine the effects of replacing CS with 2 different forage millet silage cultivars [i.e., regular millet (RM) and sweet millet $(\mathbf{S M})]$ on milk yield, milk composition, apparent totaltract nutrient digestibility, and ruminal fermentation characteristics of lactating dairy cows.

\section{MATERIALS AND METHODS}

This study was conducted at the MacDonald Campus Farm of McGill University (Sainte-Anne-de-Bellevue, QC, Canada; $45^{\circ} \mathrm{N}, 73^{\circ} \mathrm{W}$ ). All animal procedures were conducted under approval of the Animal Care Committee of the Faculty of Agriculture and Environmental Sciences of McGill University.

\section{Silage Preparation}

Two forage pearl millet hybrids, namely RM and SM, were seeded on June 1, 2012, and harvested on July 24,2012 , at the vegetative stage and approximately $1.65 \mathrm{~m}$ high. Millet seeds were provided by Bélisle Solution Nutrition Inc. (Saint-Mathias-sur-Richelieu, QC, Canada). Prior to millet seeding, $100 \mathrm{~kg}$ of urea N/ha $(46 \% \mathrm{~N})$ was evenly applied to each field. Millet $(70 \%$ moisture) was chopped into at least 12-mm particle size using a New Holland forage harvester (model 900; New Holland, New Holland, PA) and ensiled under high pressure into 45-m-long horizontal Ag-Bag silos (2.1-m diameter and approximately $50 \mathrm{t}$ each; Ag-Bag, MillerSt. Nazianz Inc., St. Nazianz, WI) for approximately 2 mo. The initial WSC content of fresh RM and SM were $74 \pm 7.46$ and $80 \pm 0.77, \mathrm{~g} / \mathrm{kg}$, respectively. The compositions of experimental silages are given in Table 1 .

\section{Animals, Experimental Design, and Diets}

Fifteen multiparous Holstein cows in early to mid lactation [milk yield: $39.9 \pm 5.60 \mathrm{~kg}$; DIM: $75.2 \pm 54.51$ d; BW: $660.2 \pm 77.41 \mathrm{~kg}$ (average $\pm \mathrm{SD}$ )] were used in a replicated $3 \times 3$ Latin square experiment with 21 -d periods (14 d of diet adaptation and $7 \mathrm{~d}$ of data collection). Cows were housed in individual tie-stalls and had free access to water. Five cows were allotted to each treatment and blocked into 5 groups of 3 by parity, milk yield, and DIM.

Three high forage isonitrogenous diets (68:32 forage:concentrate ratio) were formulated to meet nutrient requirements of lactating dairy cows in early lactation (NRC, 2001; Table 2). Experimental treatments were the replacement of CS with RM or SM silages. In all diets, the silage portion consisted of $70 \%$ CS, RM, or SM, and the remaining $30 \%$ consisted of alfalfa silage. For the objectives of this study, the proportions of experimental silages were kept constant in all dietary treatments (Table 2). Diets were offered as a TMR once daily in the morning $(0800 \mathrm{~h}$ ) for ad libitum intake. Orts were measured daily to determine daily feed intake per cow. Total mixed rations and silages were sampled daily during the data-collection periods (d 15-21 of each period) and composited by period.

\section{In Situ Ruminal Nutrient Degradabilities of Experimental Silages}

One representative sample each of CS, RM, and SM silages was obtained by mixing $200 \mathrm{~g}$ of the dried $\left(65^{\circ} \mathrm{C}\right.$ for $\left.48 \mathrm{~h}\right)$ silages from each of the 3 periods. A $5-\mathrm{g}$ subsample of each mixture was then placed into nylon bags $(20 \times 10 \mathrm{~cm}, 50-\mu \mathrm{L}$ pore size; Ankom Technology Corp., Macedon, NY) and incubated in the rumens of 3 lactating cows (1 bag per treatment per time period per cow) fed a single type of ration and fitted with rumen cannulas for $0,3,6,12,24,48,72$, and $96 \mathrm{~h}$. At the end of each incubation time, bags were removed from the rumens and manually washed under cold tap water until the water was clear. The 0 -h incubation was determined by washing the bags containing the samples. The washed bags were then dried in a forced-air oven at $65^{\circ} \mathrm{C}$ for $48 \mathrm{~h}$. In situ residues were analyzed for DM and NDF (Van Soest et al., 1991). Data of ruminal DM and NDF disappearances were used to determine nutrient kinetic parameters by using the equation of Dhanoa (1988): 
Table 1. Fermentation characteristics and chemical composition (mean $\pm \mathrm{SD}$ ) of millet and corn silages (DM basis)

\begin{tabular}{|c|c|c|c|}
\hline \multirow[b]{2}{*}{ Item } & \multicolumn{3}{|c|}{ Experimental silage $^{1}$} \\
\hline & CS & $\mathrm{RM}$ & SM \\
\hline \multicolumn{4}{|c|}{ Chemical composition, $\%$ of DM unless otherwise stated } \\
\hline $\mathrm{DM}, \%$ & $34.7 \pm 1.37$ & $26.1 \pm 1.71$ & $25.3 \pm 0.75$ \\
\hline Ash & $3.6 \pm 0.25$ & $12.1 \pm 0.65$ & $11.7 \pm 0.26$ \\
\hline $\mathrm{NDF}$ & $35.6 \pm 2.29$ & $58.4 \pm 1.62$ & $60.1 \pm 1.74$ \\
\hline $\mathrm{ADF}$ & $20.0 \pm 1.57$ & $37.6 \pm 0.39$ & $37.8 \pm 0.90$ \\
\hline $\mathrm{ADL}$ & $1.8 \pm 0.25$ & $2.5 \pm 0.15$ & $2.6 \pm 0.17$ \\
\hline $\mathrm{CP}$ & $9.6 \pm 0.30$ & $12.8 \pm 0.34$ & $13.4 \pm 0.87$ \\
\hline Soluble protein, $\%$ of $\mathrm{CP}$ & $44.1 \pm 4.66$ & $61.5 \pm 2.08$ & $58.4 \pm 2.72$ \\
\hline $\mathrm{NPN}, \%$ of $\mathrm{CP}$ & $41.5 \pm 4.30$ & $58.6 \pm 2.03$ & $56.8 \pm 3.15$ \\
\hline Neutral detergent-insoluble CP, $\%$ of CP & $16.8 \pm 0.39$ & $23.1 \pm 1.76$ & $22.8 \pm 1.76$ \\
\hline Acid detergent-insoluble CP, \% of CP & $10.9 \pm 0.10$ & $9.0 \pm 0.56$ & $8.5 \pm 0.72$ \\
\hline Starch & $29.7 \pm 1.09$ & $0.5 \pm 0.52$ & $0.2 \pm 0.07$ \\
\hline Ether extract & $2.2 \pm 0.25$ & $2.0 \pm 0.05$ & $2.0 \pm 0.10$ \\
\hline $\mathrm{NE}_{\mathrm{L}},^{2} \mathrm{Mcal} / \mathrm{kg}$ & $2.06 \pm 0.025$ & $1.65 \pm 0.006$ & $1.64 \pm 0.021$ \\
\hline \multicolumn{4}{|l|}{ Fermentation characteristics } \\
\hline $\mathrm{pH}$ & $3.95 \pm 0.06$ & $4.47 \pm 0.08$ & $4.56 \pm 0.11$ \\
\hline Water-soluble carbohydrates, \% & $2.9 \pm 0.33$ & $1.3 \pm 0.36$ & $2.4 \pm 0.34$ \\
\hline Lactic acid, \% & $6.9 \pm 0.17$ & $5.8 \pm 0.17$ & $4.6 \pm 0.20$ \\
\hline Acetic acid, \% & $1.3 \pm 0.16$ & $0.8 \pm 0.20$ & $1.7 \pm 0.03$ \\
\hline Aerobic stability, $\mathrm{h}$ & $151 \pm 15.2$ & $32 \pm 8.1$ & $125 \pm 30.4$ \\
\hline
\end{tabular}

${ }^{1} \mathrm{CS}=$ corn silage; $\mathrm{RM}=$ regular millet silage; $\mathrm{SM}=$ high water-soluble carbohydrates (sweet) millet silage.

${ }^{2}$ Estimated according to Weiss et al. (1992).

Table 2. Ingredients and chemical composition (mean \pm SD) of experimental diets

\begin{tabular}{|c|c|c|c|}
\hline \multirow[b]{2}{*}{ Item } & \multicolumn{3}{|c|}{ Dietary treatment ${ }^{1}$} \\
\hline & CS & $\mathrm{RM}$ & SM \\
\hline \multicolumn{4}{|l|}{ Ingredient, $\%$} \\
\hline Pearl millet silage & & 36.98 & \\
\hline Pearl millet silage & & & 36.58 \\
\hline Corn silage & 38.58 & & \\
\hline Alfalfa silage & 30.39 & 30.11 & 30.01 \\
\hline High-moisture corn & 19.67 & 23.01 & 23.53 \\
\hline Soybean meal & 9.8 & 6.35 & 6.33 \\
\hline Mineral premix ${ }^{2}$ & 1.56 & 1.54 & 1.54 \\
\hline Megalac $^{3}$ & & 2.01 & 2.01 \\
\hline \multicolumn{4}{|l|}{ Chemical composition, $\%$ of DM } \\
\hline DM, $\%$ & $47.2 \pm 0.83$ & $40.3 \pm 1.18$ & $41.8 \pm 2.35$ \\
\hline Ash & $5.9 \pm 0.45$ & $9.2 \pm 0.26$ & $8.4 \pm 0.55$ \\
\hline Ether extract & $2.5 \pm 0.30$ & $3.0 \pm 0.16$ & $3.1 \pm 0.38$ \\
\hline $\mathrm{NDF}$ & $32.4 \pm 1.70$ & $38.5 \pm 2.99$ & $37.9 \pm 0.41$ \\
\hline $\mathrm{ADF}$ & $19.4 \pm 1.97$ & $24.1 \pm 1.73$ & $22.8 \pm 0.59$ \\
\hline $\mathrm{ADL}$ & $2.9 \pm 0.53$ & $2.7 \pm 0.55$ & $3.0 \pm 0.35$ \\
\hline $\mathrm{CP}$ & $15.2 \pm 0.41$ & $15.5 \pm 0.36$ & $15.9 \pm 0.33$ \\
\hline Neutral detergent-insoluble CP, $\%$ of $\mathrm{CP}$ & $14.9 \pm 1.66$ & $13.6 \pm 1.83$ & $16.1 \pm 0.86$ \\
\hline Acid detergent-insoluble CP, \% of CP & $8.1 \pm 0.08$ & $7.9 \pm 0.72$ & $8.1 \pm 0.45$ \\
\hline Starch & $23.5 \pm 2.27$ & $16.4 \pm 2.41$ & $16.1 \pm 0.95$ \\
\hline NDF:starch & $1.4 \pm 0.20$ & $2.4 \pm 0.52$ & $2.3 \pm 0.11$ \\
\hline $\mathrm{NE}_{\mathrm{L}}{ }^{4}{ }^{4} \mathrm{Mcal} / \mathrm{kg}$ & $1.87 \pm 0.055$ & $1.75 \pm 0.049$ & $1.78 \pm 0.023$ \\
\hline RUP & $22.8 \pm 2.37$ & $24.8 \pm 2.19$ & $27.7 \pm 0.78$ \\
\hline
\end{tabular}

${ }^{1}$ Experimental diet (68:32 forage:concentrate ratio; DM basis) contained corn silage (CS), regular millet silage (RM), or high water-soluble carbohydrates (sweet) millet silage (SM).

${ }^{2}$ Contained $38.84 \%$ sodium bicarbonate, $25.07 \%$ dicalcium phosphate, $15.10 \% \mathrm{NaCl}, 5.35 \% \mathrm{Mg}, 4.57 \% \mathrm{~K}, 1.56 \%$ $\mathrm{Ca}, 2.04 \% \mathrm{Na}, 0.63 \% \mathrm{Zn}, 0.54 \% \mathrm{Mn}, 0.22 \% \mathrm{Cu}, 0.02 \% \mathrm{Co}, 0.01 \% \mathrm{I}, 0.01 \%$ sodium selenite, $1.38 \%$ mineral oil, $3.63 \%$ canola meal, 2,200 kIU of vitamin E/kg, 2,900 kIU of vitamin A/ $/ \mathrm{kg}$, and 1,450 kIU of vitamin D $/ \mathrm{kg}$.

${ }^{3}$ Manufactured by Church \& Dwight Co. Inc. (Princeton, NJ). Analysis: $84 \%$ fat, $12.5 \%$ ash, and 9\% Ca.

${ }^{4}$ Estimated according to Weiss et al. (1992). 


$$
\mathrm{p}=\mathrm{a}+\mathrm{b}\left(1-\mathrm{e}^{-\mathrm{c}(\mathrm{t}-\mathrm{Lt})}\right)
$$

where $\mathrm{p}$ represents the nutrient disappearance at time $\mathrm{t}$, a is the soluble fraction (\%), b is the potentially degradable fraction (\%), c is the rate of degradation of the $\mathrm{b}$ fraction $(\% / \mathrm{h})$, and $\mathrm{Lt}$ is the lag phase $(\mathrm{h})$. The parameters were estimated by PROC NLIN of SAS (SAS Institute, 2008) using iterative least squares regression (Gauss-Newton method). Effective degradabilities (ED) of DM and NDF were calculated according to the equation of Ørskov and McDonald (1979):

$$
\mathrm{ED}=\mathrm{a}+\mathrm{bc} /(\mathrm{c}+\mathrm{k}),
$$

where $\mathrm{k}$ represents the ruminal outflow rate $(6.25 \% / \mathrm{h})$, and $\mathrm{a}, \mathrm{b}$, and $\mathrm{c}$ are as described previously.

\section{Milk Production and Analysis}

Cows were milked twice daily at 0500 and $1700 \mathrm{~h}$. Milk yields were recorded at each milking by cow. Milk samples were collected twice daily on 2 consecutive days of each data-collection period, composited by cow according to volume, and analyzed for fat, protein, lactose, and MUN using an infrared analyzer (Valacta, Sainte-Anne-de-Bellevue, QC, Canada) according to the Association of Official Analytical Chemists (AOAC, 1990). Milk TS content was determined according to AOAC (1990).

\section{Ruminal Fermentation and Apparent Total-Tract Nutrient Digestibility}

Three multiparous lactating Holstein cows [milk yield: $37.8 \pm 7.5 \mathrm{~kg}$; DIM: $52.0 \pm 25.51 \mathrm{~d}$; BW: $671.5 \pm 37.75$ $\mathrm{kg}$ (average $\pm \mathrm{SD}$ )] fitted with rumen cannulas were used in a $3 \times 3$ Latin square experiment to determine the effects of dietary treatments on ruminal fermentation and total-tract nutrient digestibility. Cows were kept in tie-stalls with free access to water. The cows were fed the same experimental diets and followed the same experimental protocol as in the production study.

Rumen fluid samples were collected from different areas in the rumen with a syringe screwed to a stainless steel tube ending by a fine metal mesh (RT Rumen Fluid Collection Tube; Bar Diamond Inc., Parma, ID). The collection began before the morning feeding (0 $\mathrm{h}$ ) and $2,4,6,8,10$, and $12 \mathrm{~h}$ postfeeding on $\mathrm{d} 16$ and 17 of each period. Ruminal $\mathrm{pH}$ was determined immediately using an Accumet $\mathrm{pH}$ meter (Fisher Scientific, Montreal, QC, Canada). Thereafter, two 50-mL samples were immediately preserved by adding $5 \mathrm{~mL}$ of $25 \%$ metaphosphoric acid and $5 \mathrm{~mL}$ of $0.1 \mathrm{~N} \mathrm{HCl}$ for measurements of VFA and $\mathrm{NH}_{3}-\mathrm{N}$, respectively. Samples were kept at $-20^{\circ} \mathrm{C}$ for later analysis.

Chromic oxide was used as an inert external marker to determine total fecal output. Gelatin capsules containing $10 \mathrm{~g}$ of $\mathrm{Cr}_{2} \mathrm{O}_{3}$ were inserted into the rumen of each cow twice daily in equal intervals starting on d 10 of the adaptation period. Grabbed fecal samples were collected 4 times daily on d 15, 17, and d 21 of each period. Samples were then dried at $60^{\circ} \mathrm{C}$ in a forced-air oven for $72 \mathrm{~h}$ and pooled by cow within each period.

\section{Chemical Analysis}

Thawed samples of fresh and ensiled forages were homogenized with $500 \mathrm{~mL}$ of distilled water and the $\mathrm{pH}$ of the extract was immediately determined using an Accumet $\mathrm{pH}$ meter (Fisher Scientific). Extracts were centrifuged at $12,000 \times g$ for $15 \mathrm{~min}$ at $4^{\circ} \mathrm{C}$ and analyzed for organic acids (lactic, acetic, propionic, and butyric acid) by using HPLC (Andersson and Hedlund, 1983). The conditions for the HPLC analysis were $0.013 \mathrm{M}$ $\mathrm{H}_{2} \mathrm{SO}_{4}$ as mobile phase and a flow rate of $0.6 \mathrm{~mL} / \mathrm{min}$. Silage concentrations of WSC were determined colorimetrically within aliquots of filtered extracts using the phenolic-sulfuric acid reaction (DuBois et al., 1956).

Subsamples of silages and TMR were dried in a forced-air oven at $65^{\circ} \mathrm{C}$ for $72 \mathrm{~h}$, subsequently ground through a 1-mm screen using a Wiley mill (Arthur H. Thomas Co., Philadelphia, PA), and then analyzed for $\mathrm{DM}$, ash, and ether extract following standard procedures $(\mathrm{AOAC}, 1990)$. Crude protein $(\mathrm{N} \times 6.25)$ was analyzed using a Leco Nitrogen Analyzer (TruSpec Nitrogen Determinator System; Leco Corp., St. Joseph, $\mathrm{MI}$ ). Nonprotein $\mathrm{N}$ and soluble $\mathrm{CP}$ were determined for silages samples according to Licitra et al. (1996). Neutral detergent fiber (Van Soest et al., 1991) and ADF (AOAC, 1990) were determined using an Ankom Fiber Analyzer (Ankom Technology Corp., Macedon, NY). Analysis of NDF was performed using heatstable $\alpha$-amylase and without the use of sodium sulfite. Acid detergent lignin of TMR and silage samples was determined according to AOAC (1990). Neutral and acid detergent-insoluble protein concentrations were estimated by analyzing NDF and ADF residues, respectively, for total N (Licitra et al., 1996). Starch was analyzed colorimetrically according to McCleary et al. (1997). Gross energy (GE) of feed samples was determined using an oxygen bomb calorimeter (model 6200; Parr Instrument Co., Moline, IL).

Samples of experimental silages for the 3 periods were agitated to ensure air exposure and individually packaged loosely into $500-\mathrm{mL}$ plastic containers. Thermal insulator was wrapped around the sides of each 
container to prevent heat dissipation and 4 holes were made on the top and bottom of each container to permit air exchange. Thermocouple probes were inserted in the core of each plastic container to detect temperature difference from the environment. Aerobic stability was defined as the time required to increase the temperature by $2^{\circ} \mathrm{C}$ (Kung et al., 2000). The temperature, measured using a HotMux data logger (DDC Corp., Pennsauken, NJ), was recorded every 5 min.

Dried fecal samples were analyzed for DM, NDF, and GE as previously described. Chromic oxide content was determined according to the procedure of Fenton and Fenton (1979).

Ruminal fluid samples were centrifuged at $12,000 \times$ $g$ for $15 \mathrm{~min}$ at $4^{\circ} \mathrm{C}$ and analyzed for acetic, propionic, and butyric acids using HPLC, as described previously. Ruminal $\mathrm{NH}_{3}-\mathrm{N}$ was determined colorimetrically with a multichannel Lachat Autoanalyzer (Lachat Instruments, Milwaukee, WI).

\section{Statistical Analysis}

Data of the performance study and total-tract nutrient utilization were analyzed as a replicated $3 \times 3$ Latin square design using PROC MIXED of SAS (SAS Institute, 2008) and the following model:

$$
\mathrm{Y}_{\mathrm{ijkh}}=\mu+\operatorname{trt}_{\mathrm{i}}+\text { block }_{\mathrm{j}}+\text { animal }_{\mathrm{jk}}+\text { per }_{\mathrm{h}}+\mathrm{e}_{\mathrm{ijkh}},
$$

where $Y_{\mathrm{ijkh}}$ represents the observation, $\mu$ is the population mean, trt $_{\mathrm{i}}$ is the fixed effect of the ith treatment (i $=1,2$, or 3$)$, block $\mathrm{j}_{\mathrm{j}}$ is the fixed effect of the jth block ( $\mathrm{j}$ $=1,2,3,4$, or 5$)$, animal $_{\mathrm{jk}}$ is the random effect of the kth animal $(\mathrm{k}=1,2$, or 3$)$ in the jth block, $\mathrm{per}_{\mathrm{h}}$ is the fixed effect of the hth period $(\mathrm{h}=1,2$, or 3$)$, and $\mathrm{e}_{\mathrm{ijkh}}$ is the random error. In situ ruminal degradability data for experimental silages were analyzed using an ANOVA and a completely randomized design with treatment as main effect and cows as replicates.

Ruminal fermentation parameters data were analyzed as repeated measures in time using PROC MIXED (SAS Institute, 2008) and the following model:

$$
\begin{aligned}
\mathrm{Y}_{\mathrm{ijkh}}=\mu & +\operatorname{trt}_{\mathrm{i}}+\operatorname{animal}_{\mathrm{ij}}+\text { per }_{\mathrm{k}}+\text { time }_{\mathrm{h}} \\
& +\operatorname{trt}_{\mathrm{i}} \times \text { time }_{\mathrm{h}}+\mathrm{e}_{\mathrm{ijkh}},
\end{aligned}
$$

where $Y_{\mathrm{ijkh}}$ represents the observation, $\mu$ is the population mean, $\operatorname{trt}_{\mathrm{i}}$ is the fixed effect of the ith treatment (i $=1,2$, or 3$)$, animal $_{\mathrm{ij}}$ is the random effect of the jth cow $(\mathrm{j}=1,2$, or 3$)$ on the ith treatment, $\operatorname{per}_{\mathrm{k}}$ is the fixed effect of the kth period $(\mathrm{k}=1,2$, or 3$)$, time $_{\mathrm{h}}$ is the fixed effect of the hth time ( $\mathrm{h}=1,2,3,4,5,6$, or 7$)$; trt $_{\mathrm{i}} \times \mathrm{time}_{\mathrm{h}}$ is the interaction effect between treatment and time, and $\mathrm{e}_{\mathrm{ijkh}}$ is the residual error $\left[\mathrm{e}_{\mathrm{ijkhl}} \sim \mathrm{N}\left(0, \sigma_{\text {cow }}^{2}\right)\right]$. Significant differences were declared at $P<0.05$.

\section{RESULTS}

\section{Chemical Composition of Millet Silages and Experimental Diets}

Relative to CS, forage millet cultivars contained $66 \%$ more NDF, $88 \%$ more ADF, and $36 \%$ more CP (Table 1). Starch was higher (approximately 85 times) in CS than RM and SM silages likely due to the grain content $(30 \%)$ of CS. Corn silage also contained higher $(+0.42$ $\mathrm{Mcal} / \mathrm{kg}) \mathrm{NE}_{\mathrm{L}}$ than millet silages. However, ether extract was similar among all silage types. None of the abovementioned analyzed parameters were different between the 2 forage millet silages. However, SM contained 1.8 times higher WSC and was aerobically more stable than RM. In addition, both WSC concentrations and aerobic stability were comparable between CS and SM. Lactic and acetic acids were the main fermentation acids in all silage types, whereas butyric acid was generally undetectable (data not shown). However, a tendency existed for acetic acid concentration to be the highest in SM, whereas CS tended to contain high lactic acid levels. Both millet silages stabilized at a higher pH than CS (Table 1). However, no heat damage or putrid odors were noticed from millet silages.

\section{In Situ Ruminal Nutrient Degradability of Experimental Silages}

In contrast to forage millet silages, CS had greater $(P<0.05)$ in situ effective DM degradability but lower $(P<0.05)$ effective NDF degradability (Table 3$)$. The in situ soluble DM fraction was greater $(P<0.05)$, whereas the in situ slowly degradable DM fraction was lower $(P<0.05)$ for CS than for forage millet silages. However, CS, RM and SM had similar ruminal degradable rates for DM, soluble NDF fraction, and slowly degradable NDF fraction. Moreover, effective degradability as well as degradability of both soluble and slowly degradable fractions for DM and NDF were not influenced by forage millet cultivars.

\section{Animal Performance}

Dry matter, $\mathrm{NDF}$, starch, and $\mathrm{NE}_{\mathrm{L}}$ intakes were not affected by the 2 millet diets (Table 4 ). However, cows fed RM or SM consumed more $(P<0.05)$ NDF, but less $(P<0.05) \mathrm{DM}$, starch, and $\mathrm{NE}_{\mathrm{L}}$ than CS-fed cows. However, CP intakes were similar across dietary treatments. 
Table 3. In situ ruminal degradability of millet and corn silages

\begin{tabular}{lccccc}
\hline & \multicolumn{3}{c}{ Experimental silage $^{1}$} & & \\
\cline { 2 - 4 } Item & CS & RM & SM & SEM $^{2}$ & $P_{\text {-value }}$ \\
\hline DM & & & & & \\
Soluble fraction, \% & $57.0^{\mathrm{a}}$ & $33.3^{\mathrm{b}}$ & $34.7^{\mathrm{b}}$ & 0.85 & $<0.0001$ \\
Slowly degradable fraction, \% & $23.4^{\mathrm{b}}$ & $49.4^{\mathrm{a}}$ & $45.6^{\mathrm{a}}$ & 2.09 & 0.0002 \\
Degradation rate, \%/h & 3.5 & 4.4 & 4.5 & 0.38 & 0.21 \\
Lag time, h & 1.1 & 0.8 & 1.9 & 0.38 & 0.19 \\
Effective degradability, \% & $65.3^{\mathrm{a}}$ & $53.7^{\mathrm{b}}$ & $53.8^{\mathrm{b}}$ & 1.22 & 0.0008 \\
NDF & & & & & 0.20 \\
Soluble fraction, \% & 2.6 & 3.1 & 5.8 & 1.17 & 0.74 \\
Slowly degradable fraction, \% & 69.5 & 70.7 & 66.4 & 4.22 & 0.014 \\
Degradation rate, \%/h & $1.9^{\mathrm{b}}$ & $4.5^{\mathrm{a}}$ & $4.0^{\mathrm{a}}$ & 0.38 & 0.26 \\
Lag time, h & 1.2 & 0.4 & 1.6 & 0.50 & 0.015 \\
Effective degradability, \% & $18.9^{\mathrm{b}}$ & $32.5^{\mathrm{a}}$ & $31.7^{\mathrm{a}}$ & 2.16 & \\
\hline
\end{tabular}

${ }^{\mathrm{a}, \mathrm{b}}$ Values with different superscripts within the same row are different $(P<0.05)$.

${ }^{1} \mathrm{CS}=$ corn silage; $\mathrm{RM}=$ regular millet silage; $\mathrm{SM}=$ high water-soluble carbohydrates (sweet) millet silage.

${ }^{2}$ Pooled SEM.

${ }^{3} P$-value for treatment effects.

Milk, lactose, TS, SNF, ECM, and SCM yields were similar between cows fed CS and SM, but lower $(P<$ 0.05) among cows fed RM than CS (Table 4). Milk protein yields were highest $(P<0.05)$ for cows fed CS, intermediate $(P<0.05)$ for cows fed SM, and lowest $(P$ $<0.05)$ with RM. However, milk efficiency, and yields

Table 4. Performance of lactating dairy cows fed millet or corn silage diets

\begin{tabular}{|c|c|c|c|c|c|}
\hline \multirow[b]{2}{*}{ Item } & \multicolumn{3}{|c|}{ Dietary treatment ${ }^{1}$} & \multirow[b]{2}{*}{$\mathrm{SEM}^{2}$} & \multirow[b]{2}{*}{$P$-value ${ }^{3}$} \\
\hline & CS & $\mathrm{RM}$ & SM & & \\
\hline \multicolumn{6}{|l|}{ Intake } \\
\hline $\mathrm{DM}, \mathrm{kg} / \mathrm{d}$ & $24.4^{\mathrm{a}}$ & $22.7^{\mathrm{b}}$ & $22.8^{\mathrm{b}}$ & 0.63 & 0.0047 \\
\hline $\mathrm{DM}, \%$ of $\mathrm{BW}$ & $3.75^{\mathrm{a}}$ & $3.49^{\mathrm{b}}$ & $3.50^{\mathrm{b}}$ & 0.130 & 0.0052 \\
\hline $\mathrm{NDF}, \mathrm{kg} / \mathrm{d}$ & $7.9^{\mathrm{b}}$ & $\begin{array}{l}5.48^{\mathrm{a}} \\
8.8^{2}\end{array}$ & $8.6^{\mathrm{a}}$ & 0.24 & 0.0012 \\
\hline NDF, $\%$ of $B W$ & $1.21^{\mathrm{b}}$ & $1.35^{\mathrm{a}}$ & $1.33^{\mathrm{a}}$ & 0.050 & 0.0016 \\
\hline $\mathrm{CP}, \mathrm{kg} / \mathrm{d}$ & 3.7 & 3.5 & 3.6 & 0.09 & 0.061 \\
\hline $\mathrm{CP}, \%$ of $\mathrm{BW}$ & 0.57 & 0.54 & 0.56 & 0.020 & 0.089 \\
\hline Starch, kg/d & $5.7^{\mathrm{a}}$ & $3.7^{\mathrm{b}}$ & $3.7^{\mathrm{b}}$ & 0.22 & $<0.0001$ \\
\hline $\mathrm{NE}_{\mathrm{L}}, \mathrm{Mcal} / \mathrm{d}$ & $45.5^{\mathrm{a}}$ & $39.7^{\mathrm{b}}$ & $40.6^{\mathrm{b}}$ & 1.35 & $<0.0001$ \\
\hline \multicolumn{6}{|l|}{ Yield, $\mathrm{kg} / \mathrm{d}$} \\
\hline Milk & $35.2^{\mathrm{a}}$ & $32.7^{\mathrm{b}}$ & $34.0^{\mathrm{ab}}$ & 1.57 & 0.016 \\
\hline Fat & 1.44 & 1.37 & 1.43 & 0.071 & 0.34 \\
\hline Protein & $1.15^{\mathrm{a}}$ & $0.99^{c}$ & $1.06^{\mathrm{b}}$ & 0.038 & $<0.0001$ \\
\hline Lactose & $1.59^{\mathrm{a}}$ & $1.48^{\mathrm{b}}$ & $1.54^{\mathrm{ab}}$ & 0.075 & 0.037 \\
\hline TS & $4.53^{\mathrm{a}}$ & $4.15^{\mathrm{b}}$ & $4.38^{\mathrm{ab}}$ & 0.170 & 0.0046 \\
\hline SNF & $3.10^{\mathrm{a}}$ & $2.78^{\mathrm{b}}$ & $2.94^{\mathrm{ab}}$ & 0.116 & 0.0017 \\
\hline ECM & $38.0^{\mathrm{a}}$ & $35.2^{\mathrm{b}}$ & $37.0^{\mathrm{ab}}$ & 1.52 & 0.018 \\
\hline SCM & $35.3^{\mathrm{a}}$ & $32.7^{\mathrm{b}}$ & $34.4^{\mathrm{ab}}$ & 1.38 & 0.014 \\
\hline $4 \% \mathrm{FCM}$ & 35.6 & 33.7 & 35.1 & 1.54 & 0.10 \\
\hline Milk efficiency ${ }^{4}$ & 1.46 & 1.46 & 1.51 & 0.070 & 0.34 \\
\hline \multicolumn{6}{|l|}{ Composition, \% } \\
\hline Fat & 4.09 & 4.25 & 4.27 & 0.185 & 0.37 \\
\hline Protein & $3.30^{\mathrm{a}}$ & $3.04^{\mathrm{c}}$ & $3.14^{\mathrm{b}}$ & 0.092 & $<0.0001$ \\
\hline Lactose & 4.50 & 4.53 & 4.52 & 0.043 & 0.66 \\
\hline TS & 12.93 & 12.76 & 12.95 & 0.273 & 0.50 \\
\hline SNF & $8.84^{\mathrm{a}}$ & $8.51^{\mathrm{b}}$ & $8.69^{\mathrm{ab}}$ & 0.142 & 0.035 \\
\hline MUN, mg/dL & $8.6^{\mathrm{b}}$ & $10.1^{\mathrm{a}}$ & $10.8^{\mathrm{a}}$ & 0.88 & 0.0001 \\
\hline
\end{tabular}

${ }^{\mathrm{a}-\mathrm{C}}$ Values with different superscripts within the same row are different $(P<0.05) .{ }^{1}$ Experimental diet $(68: 32$ forage:concentrate ratio; DM basis) contained corn silage (CS), regular millet silage (RM), or high watersoluble carbohydrates (sweet) millet silage (SM).

${ }^{2}$ Pooled SEM.

${ }^{3} P$-value for treatment effects.

${ }^{4}$ Milk yield/DMI. 
Table 5. Total-tract nutrient digestibility and ruminal fermentation of lactating dairy cows fed millet or corn silages in the diet

\begin{tabular}{lccccc}
\hline & \multicolumn{3}{c}{ Dietary treatment $^{1}$} & & \\
\cline { 2 - 3 } Item & CS & RM & SM & SEM $^{2}$ & $P$-value $^{3}$ \\
\hline Total-tract digestibility, $\%$ & & & & \\
DM & 70.43 & 66.02 & 67.34 & 1.822 & 0.50 \\
OM & 71.72 & 68.78 & 69.86 & 1.748 & 0.65 \\
CP & 65.68 & 61.48 & 62.75 & 2.128 & 0.58 \\
NDF & 52.69 & 53.06 & 55.85 & 3.687 & 0.82 \\
GE & 68.40 & 66.68 & 68.67 & 2.456 & 0.83 \\
Starch & 91.27 & 90.39 & 89.44 & 1.924 & 0.83 \\
Ruminal fermentation & & & & & \\
pH & $5.77^{\mathrm{b}}$ & $6.04^{\mathrm{a}}$ & $6.12^{\mathrm{a}}$ & 0.063 & $<0.0001$ \\
NH ${ }_{3}-\mathrm{N}, \mathrm{mg} / \mathrm{dL}$ & $9.9^{\mathrm{b}}$ & $15.0^{\mathrm{a}}$ & $14.6^{\mathrm{a}}$ & 1.09 & 0.0007 \\
VFA, m $M$ & $134.9^{\mathrm{a}}$ & $133.1^{\mathrm{ab}}$ & $128.7^{\mathrm{b}}$ & 4.88 & 0.011 \\
Molar proportion, $\%$ & & & & & \\
Acetate & $56.4^{\mathrm{b}}$ & $65.6^{\mathrm{a}}$ & $63.9^{\mathrm{a}}$ & 1.49 & 0.0002 \\
Propionate & $30.1^{\mathrm{a}}$ & $22.9^{\mathrm{b}}$ & $24.9^{\mathrm{ab}}$ & 1.21 & 0.031 \\
Butyrate & 13.5 & 11.5 & 11.2 & 1.09 & 0.21 \\
Acetate:propionate & $1.98^{\mathrm{b}}$ & $3.01^{\mathrm{a}}$ & $2.74^{\mathrm{a}}$ & 0.160 & 0.0002 \\
\hline
\end{tabular}

${ }^{\mathrm{a}, \mathrm{b}}$ Values with different superscripts within the same row are different $(P<0.05) .{ }^{1}$ Experimental diet $(68: 32$ forage:concentrate ratio; DM basis) contained corn silage (CS), regular millet silage (RM), or high watersoluble carbohydrates (sweet) millet silage (SM).

${ }^{2}$ Pooled SEM.

${ }^{3} P$-value for treatment effects.

${ }^{4}$ Gross energy.

of fat and $4 \%$ FCM were not affected by dietary treatments. With the exception of milk protein yields, none of the milk yields were different between RM and SM.

Protein concentration was highest in the milk of cows fed CS, intermediate for cows fed SM, and lowest for cows fed RM $(P<0.05$; Table 4$)$. However, milk fat, lactose and TS levels were similar across experimental diets. Cows fed CS produced milk with greater $(P<$ 0.05) SNF than RM; however, similar milk SNF levels were recorded between CS- and SM-fed cows. Cows fed CS produced milk with lower $(P<0.05)$ MUN levels than for those fed RM and SM.

\section{Ruminal Fermentation and Total Apparent Nutrient Digestibility}

No treatments $\times$ time interactions were significant for any of the ruminal fermentations (Table 5). Therefore, only main treatment effects were reported. Ruminal $\mathrm{pH}$ and $\mathrm{NH}_{3}-\mathrm{N}$ concentrations were greater $(P$ $<0.05)$ for cows fed RM or SM relative to cows fed CS. Total VFA levels were lower $(P<0.05)$ for SM-fed cows than for CS-fed cows. However, total VFA was not different between cows fed CS and RM or SM and RM. Feeding forage millet diets relative to CS increased $(P<0.05)$ molar proportions of acetate, whereas the molar proportion of propionate was greater $(P<0.05)$ for cows fed CS than for cows fed RM. Consequently, the acetate:propionate ratio was increased $(P<0.05)$ as a result of feeding forage millet diets relative to CS. Ruminal butyrate levels were not affected by dietary treatments. Apparent total-tract digestibility of DM, $\mathrm{CP}, \mathrm{NDF}, \mathrm{GE}$, and starch were not influenced by silage type and averaged $67.93,63.30,53.87,67.92$, and $90.37 \%$, respectively (Table 5 ).

\section{DISCUSSION}

This study investigated the effects of replacing CS with a regular or high-WSC forage millet silage in the diets of lactating dairy cows on milk production, rumen fermentation characteristics, and total-tract nutrient digestibility. Corn silage contained approximately $30 \%$ grains (Chase, 2012). In contrast, unlike grain millet cultivars, the 2 forage millet cultivars were harvested at the vegetative stage and before seed setting. If experimental diets were to be balanced for starch, the RM and SM rations would have necessitated additional grains (i.e., high-moisture corn). However, to better reflect dairy production in the more temperate regions whereby CS and corn grains are extremely limited, we deliberately formulated diets with replacement of equal proportions of CS with RM or SM. The CS diet contained 85 times more starch than the RM or SM diet (Table 2). Calcium salts of palm oil (Megalac; Church \& Dwight Co. Inc., Princeton, NJ) were added to the $\mathrm{RM}$ and $\mathrm{SM}$ diets to balance for $\mathrm{NE}_{\mathrm{L}}$ across dietary treatments. 
In this study, forage millet silages contained $66 \%$ more NDF, $88 \%$ more $\mathrm{ADF}$, and $36 \%$ more CP compared with CS (Table 2). However, the nutritive values of both forage millet cultivars were equivalent. The greater residual WSC concentration of SM relative to $\mathrm{RM}$ is likely due to the lower utilization of WSC by lactic acid bacteria. The greater concentration of acetic acid may explain the higher aerobic stability of CS and $\mathrm{SM}$ relative to RM. Increases in acetic acid concentration in silages treated with Lactobacillus buchneri improved aerobic stability in barley silages (Kung et al., 2000). Values of NDF and CP of millet silages were in agreement with Messman et al. (1992) and Ward et al. (2001). In contrast to our previous study with high WSC millet (Amer and Mustafa, 2010), SM had comparable CP and ADF levels but lower (11\%) NDF level. The lower NDF contents of SM may be attributed to differences in maturity stages (vegetative vs. heading) at which millet was harvested and ensiled. Advancement in maturity of grass forages is usually associated with reduced $\mathrm{CP}$, and increased NDF and ADF contents (Rinne et al., 1997; Cone et al., 1999; Holtshausen et al., 2012). However, this was not evidenced when comparing the findings of our study with those of Amer and Mustafa (2010).

Forage millet had a higher effective in situ degradability of NDF than CS (Table 3). Our findings were somewhat expected, given the fact that advanced maturity of forages is negatively correlated with fiber (NDF and ADF) digestibility (Rinne et al., 2002; Holtshausen et al., 2012). Whereas CS is normally harvested at mature stages, forage millet was harvested earlier at the vegetative stage. The higher $\mathrm{CP}$ contents and greater quantities of more effectively degradable fiber of forage millet make it an interesting silage in dairy cow diets. In contrast, the higher DM degradability of CS than RM and SM as observed in the current study were mainly due to its higher WSC contents and, in particular, starch. Starch of corn grains is a rapidly fermentable carbohydrate in the cow rumen. In agreement with our findings, Amer and Mustafa (2010) reported higher in vitro DM but lower in vitro NDF disappearance for CS than forage millet silage. However, RM and SM had similar nutritive values and in situ degradability of $\mathrm{DM}$ and NDF, given that these were harvested at same maturity (vegetative) stage.

Total-tract digestibility of DM, CP, and NDF were not affected by dietary treatments (Table 5). However, in the production study (Table 4), dairy cows fed forage millet diets consumed greater NDF than those fed CS, likely because RM and SM were ruminally more degradable than CS or due to the higher NDF contents of millet diets. Similar findings have previously been reported. For instance, Amer and Mustafa (2010) re- ported that dairy cows fed millet silage consumed more NDF (1.35 vs. $1.18 \%$ of BW) than when fed a CS diet. Ward et al. (2001) observed that heifers fed pearl millet silage consumed more NDF than those fed sorghum or tropical CS. On the other hand, cows fed CS consumed higher DM as a result of its higher starch intake (Table 4). However, DMI was not influenced by forage millet silages. Previous studies indicated that cows fed pearl millet consumed greater (Ward et al., 2001), similar (Amer and Mustafa, 2010), or less (Messman et al., 1992; Kochapakdee et al., 2002) DM than cows fed CS. Inconsistent findings between studies may be related to factors such as the forage:concentrate ratio, maturity stage at which millet was harvested, and diet composition.

Our findings indicated that milk yield was greater among cows fed CS than RM, but not compromised when cows were fed the SM diet (Table 4). The lower milk production recorded among RM-fed cows relative to CS-fed cows is most likely due to their lower DM (starch) and $\mathrm{NE}_{\mathrm{L}}$ intakes. Kochapakdee et al. (2002) also reported a $12 \%$ reduction in milk yield as a result of feeding cows pearl millet silage compared with CS. However, despite the lower $\mathrm{DM}$ and $\mathrm{NE}_{\mathrm{L}}$ intakes among cows fed SM compared with CS, their similarity in milk yield is difficult to explain at this time. In agreement with our findings, unaffected milk yields between cows fed high-WSC pearl millet silage and CS have previously been reported (Amer and Mustafa, 2010).

Higher milk yield and milk protein levels, but lower milk fat concentrations are typically observed among dairy cows fed high-starch diets (Table 4). The lower carbohydrate intake (i.e., lower supply of gluconeogenic precursors, such as propionate) and lower intakes of MP (soybean meal) may explain the reduction in milk protein concentration due to feeding forage millet silages (Broderick, 2003; Jenkins and McGuire, 2006). Our explanation about lower MP intake or amino acid supply is consistent with the increases in ruminal $\mathrm{NH}_{3-}$ $\mathrm{N}$ concentrations (Table 5). Reductions in milk protein levels among cows fed pearl millet silage compared with CS were also observed by Messman et al. (1992) and Kochapakdee et al. (2002).

In the present study, we observed a reduction in ruminal $\mathrm{NH}_{3}-\mathrm{N}$ for cows fed CS relative to those fed millet silages. Our findings are in agreement with Brito and Broderick (2006) and Hassanat et al. (2013), who also reported a decrease in ruminal $\mathrm{NH}_{3}-\mathrm{N}$ concentration with increasing proportions of CS in the diets, and associated this effect with reduced urinary $\mathrm{N}$ losses. In fact, when $\mathrm{NH}_{3}-\mathrm{N}$ level in the rumen exceeds microbial uptake, excess $\mathrm{NH}_{3}-\mathrm{N}$ is absorbed through the rumen, transferred to the liver, metabolized into urea, and excreted in urine (Van Soest, 1994). However, $\mathrm{NH}_{3} \mathrm{~N}$ 
utilization in the rumen is mainly affected by carbohydrate availability (Russell et al., 1992). According to Hristov et al. (2005), higher intakes of fermentable carbohydrates may reduce $\mathrm{NH}_{3}-\mathrm{N}$ synthesis in the rumen (by reducing the deamination of AA or enhancing microbial capture of released AA) or increase $\mathrm{NH}_{3}-\mathrm{N}$ utilization by the rumen microbes.

Feeding cows forage millet silages compared with CS caused substantial changes in the ruminal environment (Table 5 ). The higher starch contents (23.5 vs. $16.3 \%$ of DM) of the CS diet led to an acidic ruminal environment (average $\mathrm{pH}$ of 5.77 vs. 6.08) and shifted the VFA pattern toward proportionally more propionate at the expense of acetate (Bradford et al., 2006). In the current study, cows fed the CS diet consumed $45 \%$ more starch than RM- or SM-fed cows. Ruminal fermentation of starch produces more propionate than fermentation of other carbohydrates such as glucose, fructose, and sucrose (Heldt et al., 1999). In agreement with our findings, Messman et al. (1992) reported greater molar proportions of acetate and acetate:propionate ratio, but lower propionate proportions when cows were fed a combination of pearl millet and alfalfa silages than for cows fed a combination of corn and alfalfa silages. Reports indicate that low ruminal $\mathrm{pH}$ favors lower acetate:propionate ratio (Lana et al., 1998). In general, a higher acetate:propionate ratio is an indicator of lipogenic versus glycogenic VFA production (Messman et al., 1992). The significantly lower acetate proportion in the rumen of cows fed the CS diet may be associated with lower in situ ruminal NDF degradation. Fibrolytic activity in the rumen may be impaired when feeding cows diets rich in fermentable carbohydrates. At low rumen $\mathrm{pH}$ (6.0 to 5.8), growth or activity of cellulolytic bacteria is compromised and, hence, so is fiber digestibility (Russell et al., 1992).

\section{CONCLUSIONS}

Under the condition of a high forage:concentrate diet, feeding cows forage millet silages in replacement of CS reduced DMI, milk yield (RM only), and milk protein concentration, likely because of higher NDF and lower starch contents. Nevertheless, cows fed pearl millet diets consumed more NDF because pearl millet silages were ruminally more degradable than CS. Forage millet diets necessitated less $(<55 \%)$ soybean meal, given that forage millet silages contained $36 \%$ higher CP than CS. The effects of forage millet cultivars had minimal influence on the performance of dairy cows due to similarity in chemical compositions, in situ degradability, nutrient digestibility, and rumen fermentation. Finally, based on findings of this study, forage millet silages may be an alternative to CS, especially in the more temperate regions.

\section{ACKNOWLEDGMENTS}

T. Brunette is a recipient of an Industrial Innovation Scholarship from Fonds Québécois de la Recherche sur la Nature et les Technologies (FQRNT, Quebec, QC, Canada), Natural Sciences and Engineering Research Council of Canada (NSERC, Ottawa, ON, Canada), and Bélisle Solution Nutrition Inc. (Saint-Mathias-surRichelieu, QC, Canada). The authors thank N. Gentesse and P. Vincent (Bélisle Solution Nutrition Inc.) for technical support.

\section{REFERENCES}

Adesogan, A. T., N. Krueger, M. B. Salawu, D. B. Dean, and C. R. Staples. 2004. The influence of treatment with dual purpose bacterial inoculants or soluble carbohydrates on the fermentation and aerobic stability of bermudagrass. J. Dairy Sci. 87:3407-3416.

Amer, S., and A. F. Mustafa. 2010. Effects of feeding pearl millet silage on milk production of lactating dairy cows. J. Dairy Sci. 93:5921-5925.

Andersson, R., and B. Hedlund. 1983. HPLC analysis of organic acids in lactic acid fermented vegetables. Z. Lebensm. Unters. Forsch. 176:440-443.

AOAC. 1990. Official Methods of Analysis. 15th ed. Vol. 1 Assoc. Off. Anal. Chem., Arlington, VA.

Bradford, B. J., A. D. Gour, A. S. Nash, and M. S. Allen. 2006. Chal lenges have limited value for investigating bovine metabolism. J. Nutr. 136:1915-1920.

Brito, A. F., and G. A. Broderick. 2006. Effect of varying dietary ratios of alfalfa silage to corn silage on production and nitrogen utilization in lactating dairy cows. J. Dairy Sci. 89:3924-3938.

Broderick, G. A. 2003. Effects of varying dietary protein and energy levels on the production of lactating dairy cows. J. Dairy Sci. 86:1370-1381.

Chase, L. E. 2012. Estimating corn grain and corn silage yields. Dairy Nutrition Fact Sheet. Accessed Feb. 5, 2014. http://www.ansci. cornell.edu/pdfs/EstmtCornGrainSilgYld.pdf.

Cone, J. W., A. H. Van Gelder, I. A. Soliman, H. De Visser, and A. M. Van Vuuren. 1999. Different techniques to study rumen fermentation characteristics of maturing grass and grass silage. J. Dairy Sci. 82:957-966.

Dhanoa, M. S. 1988. On the analysis of Dacron bag data for low degradability feeds. Grass Forage Sci. 43:441-444.

DuBois, M. A., K. A. Gilles, J. K. Hamilton, P. A. Rebers, and F. Smith. 1956. Colorimetric methods for determination of sugars and related substances. Anal. Chem. 28:350-356.

Fenton, T. W., and M. Fenton. 1979. An improved procedure for the determination of chromic oxide in feed and feces. Can. J. Anim. Sci. 58:631-634.

Hanna, W. W. 1995. Breeding pearl millet for grain production. Pages 8-12 in Proc. Natl. Grain Pearl Millet Symp., Tifton, GA. University of Georgia, Tifton.

Hassanat, F., R. Gervais, C. Julien, D. I. Masse, A. Lettat, P. Y. Chouinard, H. V. Petit, and C. Benchaar. 2013. Replacing alfalfa silage with corn silage in dairy cow diets: Effects on enteric methane production, ruminal fermentation, digestion, $\mathrm{N}$ balance, and milk production. J. Dairy Sci. 96:4553-4567.

Heldt, J. S., R. C. Cochran, G. L. Stokka, C. G. Farmer, C. P. Mathis, E. C. Titgemeyer, and T. G. Nagaraja. 1999. Effects of different supplemental sugars and starch fed in combination with degradable intake protein on low-quality forage use by beef steers. J. Anim. Sci. 77:2793-2802. 
Holtshausen, L., S. H.-O. Liestøl, S. K. Nes, K. A. Beauchemin, O. M. Harstad, and T. A. McAllister. 2012. Effect of maturity at harvest on in vitro methane production from ensiled grass. Acta Agric. Scand. A Anim. Sci. 62:40-45.

Hristov, A. N., J. K. Ropp, K. L. Grandeen, S. Abedi, R. P. Etter, A. Melgar, and A. E. Foley. 2005. Effect of carbohydrate source on ammonia utilization in lactating dairy cows. J. Anim. Sci. 83:408-421.

Jenkins, T. C., and M. A. McGuire. 2006. Major advances in nutrition: Impact on milk composition. J. Dairy Sci. 89:1302-1310.

Kochapakdee, S., B. R. Moss, J. Lin, D. W. Reeves, W. H. McElhenney, P. Mask, and E. van Santen. 2002. Evaluation of white lupin, temperate corn, tropical corn, and hybrid pearl millet silage for lactating cows. Pages 300-307 in Proc. 10th International Lupin Conf., Laugarvatn, Iceland. International Lupin Association, Canterbury, New Zealand.

Kung, L., Jr., J. R. Robinson, N. K. Ranjit, J. H. Chen, C. M. Golt, and J. D. Pesek. 2000. Microbial population, fermentation end products, and aerobic stability of corn silage treated with ammonia or propionic acid-based preservative. J. Dairy Sci. 83:1479-1486.

Lana, R. P., J. B. Russell, and M. E. Van Amburgh. 1998. The role of $\mathrm{pH}$ in regulating ruminal methane and ammonia production. J. Anim. Sci. 76:2190-2196.

Licitra, G., T. M. Hernandez, and P. J. Van Soest. 1996. Standardization procedures for nitrogen fractionation of ruminant feeds. Anim. Feed Sci. Technol. 57:347-358.

Maiti, R., and P. Wesche-Ebeling. 1997. Pearl Millet Science. Science Publishers Inc., Enfield, NH.

McCleary, B. V., T. S. Gibson, and D. C. Mugford. 1997. Measurement of total starch in cereal products by amyloglucosidase $\alpha$-amylase method: Collaborative study. J. AOAC Int. 80:571-579.

Messman, M. A., W. P. Weiss, P. R. Henderlong, and W. L. Shockey. 1992. Evaluation of pearl millet and field peas plus triticale silages for midlactation dairy cows. J. Dairy Sci. 75:2769-2775.
NRC. 2001. Nutrient Requirements of Dairy Cattle. 7th rev. ed. Natl. Acad. Press, Washington, DC.

Rinne, M., P. Huhtanen, and S. Jaakkola. 2002. Digestive processes of dairy cows fed silages harvested at four stages of grass maturity. J. Anim. Sci. 80:1986-1998.

Rinne, M., S. Jaakkola, and P. Huhtanen. 1997. Grass maturity effects on cattle fed silage-based diets. 1. Organic matter digestion, rumen fermentation and nitrogen utilization. Anim. Feed Sci. Technol. $67: 1-17$.

Ørskov, E. R., and I. McDonald. 1979. The estimation of protein degradability in the rumen from incubation measurements weighed according to rate of passage. J. Agric. Sci. 92:499-503.

Russell, J. B., J. D. O'Connor, D. G. Fox, P. J. Van Soest, and C. J Sniffen. 1992. A net carbohydrate and protein system for evaluating cattle diets: I. Ruminal fermentation. J. Anim. Sci. 70:35513561.

SAS Institute. 2008. SAS/STAT 9.2 User's Guide: Statistics. SAS Inst. Inc., Cary, NC.

Van Soest, P. J. 1994. Nutritional Ecology of the Ruminant. 2nd ed. Cornell Univ. Press, Ithaca, NY.

Van Soest, P. J., P. J. Robertson, and B. A. Lewis. 1991. Methods for dietary fiber, neutral detergent fiber, and nonstarch polysaccharides in relation to animal nutrition. J. Dairy Sci. 74:3583-3597.

Ward, J. D., D. D. Redfearn, M. E. McCormick, and G. J. Cuomo 2001. Chemical composition, ensiling characteristics, and apparent digestibility of summer annual forages in a subtropical doublecropping system with annual ryegrass. J. Dairy Sci. 84:177-182.

Weiss, W. P., H. R. Conrad, and N. R. St. Pierre. 1992. A theoretically based model for predicting total digestible values for forages and concentrates. Anim. Feed Sci. Technol. 39:95-110. 